\title{
Evidencing STEM Content Knowledge Transfer: Abstraction in Technological/Engineering Design Challenges
}

\author{
Fred J. Figliano \& John G. Wells
}

\begin{abstract}
This study outlines the development of the Design Log Instrument (DLI), which is intended for use in identifying moments of abstraction as evidence of STEM content knowledge transfer. The DLI prompts participants to be reflective during technological/engineering design challenges. During the development of this instrument, a three-phase, multiple-case, embedded design was used. Three distinct phases accommodated the collection and analysis of data necessary for this investigation: (1) pilot case study, (2) establishing content validity, and (3) establishing construct validity. During Phase 3, data from the DLI were collected at each of seven work sessions from two undergraduate design teams working through different engineering problems. At the end of Phase 3, a comparison of abstractions found in DLI responses and observation data (audio/video transcripts) indicated the extent to which the DLI independently reflected the abstractions revealed in observations (audio/video transcripts). The results of this comparison showed that the DLI has the potential to be $68 \%$ reliable in revealing abstracted knowledge.
\end{abstract}

Keywords: Abstraction; knowledge transfer; STEM; technological/engineering design; design log

Few would argue that in the past decade, science, technology, engineering, and mathematics (STEM) literacy has become a significant driving force in 21st-century education (Honey, Pearson, \& Schweingruber, 2014; National Research Council, 2011; Partnership for 21st Century Skills, 2011). A STEMliterate population provides the basis for America's global competitiveness, and its central tenet is the preparation of individuals who recognize and understand the connections between STEM content and practices. Such preparation calls for divergence from the traditional silo method of education whereby STEM disciplines are taught independent of one another. A more authentic pathway for achieving STEM literacy follows the integrative STEM education (I-STEM ED) approach in which disciplinary content and practice are concurrently and intentionally taught within design-based learning environments (Change the Equation, 2016; International Technology and Engineering Educators Association, 2015; Katehi, Pearson, \& Feder, 2009; Kelley, 2008; Wells, 2008, 2016a, 2016b, 2017). 
In Technology and engineering education (TEE), I-STEM ED is often defined as

'the application of technological/engineering design based pedagogical approaches to intentionally teach content and practices of science and mathematics education through the content and practices of technology/engineering education. Integrative STEM Education is equally applicable at the natural intersections of learning within the continuum of content areas, educational environments, and academic levels' (Wells \& Ernst, 2012/2015). (Virginia Polytechnic Institute and State University, 2019, para. 4)

TEE utilizes the I-STEM ED approach to intentionally teach science, technology, engineering, and mathematics content and practice within the design of real-world technological and engineering solutions. As such, technological/engineering $(\mathrm{T} / \mathrm{E})$ design challenges have great potential as a valid instructional strategy for developing the higher order cognitive skills needed in the 21st century (Partnership for 21st Century Skills, 2011; Wells, 2010, 2016a, $2016 \mathrm{~b}, 2017)$. Instructionally, throughout any $\mathrm{T} / \mathrm{E}$ design challenge, there are multiple opportunities for students to intentionally use the knowledge acquired in one discipline together with that from another to solve a design problem. For example, if a student is attempting to design the trusses for a bridge, the student will need to have some understanding of the connections to the forces (load, sheer, etc.), material properties, and measurements within this context. Most of this knowledge is gained in the study of the physical sciences. The student would also need to understand how to decide what mathematical calculations are best in helping to solve this design problem. This process of activating disciplinary knowledge gained in one context and used in another is characterized as knowledge transfer, which is traditionally defined as "the ability to apply knowledge or use knowledge from one problem, situation or context to another" (Anderson, 2005; as cited in Pitts Bannister \& Mariano, 2015, p. 139). To support the design used in the research being presented, the following operationalized version of Anderson's (2005) definition provided the basis for assessing student demonstration of knowledge transfer: the abstraction of any knowledge, information, or experiences by participants and used when trying to understand higher order concepts. The use of $\mathrm{T} / \mathrm{E}$ design challenges within such instructional environments is uniquely suited to fostering knowledge transfer because of the cognitive demand for STEM content and practice knowledge that is inherently imposed on the learner within any given $\mathrm{T} / \mathrm{E}$ design challenge (Wells, 2016b, 2017). The intent of the research presented was to provide evidence of the potential for $\mathrm{T} / \mathrm{E}$ design challenges to foster the transfer of STEM content knowledge. 


\section{Research Design}

Evidencing the potential of T/E design challenges to foster knowledge transfer required a mechanism for documenting that transfer. While working through a design problem, many decisions are made based on different information. It can be challenging to capture those decisions and the logic behind them. For that reason, the researchers felt that a formative instrument was needed rather than a summative instrument such as a standardized posttest. The purpose of this study was to develop an instrument with undergraduate engineering students that could provide data demonstrating student transfer of STEM content knowledge. Utilizing a case-study approach, this study sought to answer the following research questions:

- In what ways does the use of a design log provide evidence of the transfer of STEM content knowledge while students are engaged in a technological/engineering design-based learning challenge?

- RQ-S1: What phrasing of design log reflective prompts effectively reveal STEM content connections?

- RQ-S2: To what extent can a design log instrument allow a researcher to make judgments regarding the transfer of STEM content knowledge?

The research design for this study employed a multiple-case, embedded design. Multiple T/E design teams comprised the cases in this study, and individual students within each team comprised the embedded units of analysis (see Yin, 2009, p. 29). In the context of this study, data from each participant within a team were independently collected and analyzed as a distinct embedded unit of analysis. As such, the multiple-case, embedded design approach was appropriate for accommodating the process of instrument development by allowing for instrument modification over three phases of administration with multiple T/E design teams (see Yin, 2009). Triangulation of data collected from $\mathrm{T} / \mathrm{E}$ design teams and interview data from both teams and individual participants (units of analysis) was conducted to identify points of convergence regarding the transfer of STEM content knowledge across all data sources.

Previous studies addressing knowledge transfer served as references for considering what data sources would be adequate for answering each research question across all three phases of data collection and analysis (Barlex \& Trebell, 2008; Hill, 1997; Kelly, 2008; Kolodner, 2002; Kolodner et al., 2003; Puntambekar \& Kolodner, 1998, 2005). Data necessary for investigating the research questions were generated, collected, and analyzed across the following three distinct phases: (1) pilot case study, (2) establishing content validity, and (3) establishing construct validity. Data sources included interviews, field notes, design logs, and audio/video recordings of participant work sessions. During all periods of student engagement in the $\mathrm{T} / \mathrm{E}$ design challenges, data were collected 
concurrently in order to provide the necessary mechanism for data convergence through triangulation.

\section{Participants}

This study describes the initial development of the Design Log Instrument. For that reason, the researchers felt that undergraduate engineering students were well suited to participate. By using these students, it was possible to refine the instrument at a higher level. The researchers did not intend for this instrument to be used in a $\mathrm{K}-12$ classroom in its current state, though that may be possible in the future.

The nature of this instrument development required the participation of individuals involved in T/E design challenges. Such individuals were drawn from the college of engineering at a major university in which design is a central focus of the curriculum. Undergraduate engineering students, specifically those in engineering science (ES), were targeted for this study. The ES department is uniquely suited to accommodate research investigating the transfer of STEM content knowledge in T/E design challenges because of their focus on intentionally necessitating the transfer of STEM content knowledge to solve T/E design problems. ES programs "focus on imparting and using fundamental interdisciplinary skills that address engineering problems" (Puri, 2008). Particularly immersed in T/E design are senior undergraduate engineering students in ES during their required fourth-year, capstone, design course, which is designed to foster their use of knowledge learned in previous college courses. During this capstone course, seniors work in teams to solve a T/E design challenge. Senior capstone design teams were selected to participate in Phase 1 (the pilot case study). At this particular southeastern university, sophomore ES students are also engaged in $\mathrm{T} / \mathrm{E}$ design challenges in teams as a way to expose them to design at an early stage in their collegiate engineering preparation. Sophomore teams were selected to participate in Phase 3, during which construct validity of the Design Log Instrument was to be established.

\section{Phase 1: Pilot Case Study}

Phase 1 was conducted to develop the initial Design Log Instrument (DLI). Assessment of the initial DLI occurred over a period of 5 weeks with senior capstone teams engaged in a T/E design challenge. Two design teams met once a week for the duration of the 5 weeks. Concurrent collection of audio/video recordings and field-note data occurred during each work session. At the end of each work session, data were collected from both team interviews, and the DLI administered to each team member. Triangulation of these data points provided the basis for iterative DLI revisions across the 5 weeks. The primary data source for DLI revisions was the interviews conducted at the end of each work session, which provided participant feedback for evaluating the clarity of the reflective prompts. The coding of these data provided information about participant 
perceptions of the DLI and its ease of use. Based on the collective responses of all participants, the DLI was modified to improve the use of the prompts and increase their ability to report instances of transfer.

Triangulation of data points was used to judge the degree to which participant responses to the DLI corresponded with the field notes and audio/video recording transcripts as a means for establishing the validity and reliability of the DLI as an independent measure of transfer. The triangulation process described above was instrumental in making iterative revisions to the DLI following each weekly session with both design teams. A comparison of the initial and final iteration of the DLI reflective prompts is presented in Table 1.

Table 1

Comparison of Initial and Final DLI Prompt Iterations

\begin{tabular}{|c|c|c|}
\hline Prompt \# & Initial reflective prompt & $\begin{array}{c}\text { Final iteration of reflective } \\
\text { prompt }\end{array}$ \\
\hline 1 & $\begin{array}{l}\text { Of all the tasks you have } \\
\text { worked through during this } \\
\text { work session, which have you } \\
\text { started to work on but have } \\
\text { not completed? }\end{array}$ & $\begin{array}{l}\text { Look at your notes on the } \\
\text { previous page and identify the } \\
\text { main topics that were discussed } \\
\text { during this work session. }\end{array}$ \\
\hline 2 & $\begin{array}{l}\text { What information did you } \\
\text { need to search for that you did } \\
\text { not already know and what } \\
\text { knowledge did you already } \\
\text { have that you used during this } \\
\text { work session? }\end{array}$ & $\begin{array}{l}\text { Considering the phase(s) you } \\
\text { indicated on the previous page } \\
\text { and the main topics you listed in } \\
\text { question one, what Science, } \\
\text { Technology, Engineering, and } \\
\text { Mathematics (STEM) content } \\
\text { did you know and what STEM } \\
\text { content did you not know about } \\
\text { each topic? }\end{array}$ \\
\hline 3 & $\begin{array}{l}\text { How did you solve any } \\
\text { problems that arose during } \\
\text { this work session? }\end{array}$ & $\begin{array}{l}\text { List any design constraints, } \\
\text { design trade-offs, or design } \\
\text { failures that you were } \\
\text { confronted with during this } \\
\text { work session. Then explain how } \\
\text { what you were confronted with } \\
\text { allowed you to improve your } \\
\text { proposal (design solution). }\end{array}$ \\
\hline 4 & $\begin{array}{l}\text { Based on the expectations for } \\
\text { your final solution that were } \\
\text { framed in phase } 2 \text {, how does } \\
\text { the work you completed } \\
\text { during this work session align } \\
\text { with those expectations? }\end{array}$ & $\begin{array}{l}\text { Looking at the design } \\
\text { constraints, design trade-offs, or } \\
\text { design failures you listed in } \\
\text { question three, how do those } \\
\text { modifications affect your } \\
\text { original proposal (design) }\end{array}$ \\
\hline
\end{tabular}




\begin{tabular}{cll} 
Journal of Technology Education & Vol. 31 No. 1, Fall 2019 \\
\hline & & \\
\hline 5 & How would you predict your & scenario criteria? \\
& final solution to work based & question four, how do you \\
on the decisions which you & predict they will influence your \\
have made during this work & final proposal (design solution)? \\
session? & Explain your answer. \\
\hline
\end{tabular}

As illustrated in Table 1, iterative revisions to the DLI were derived from and are reflective of the data analysis and participant responses to the interview questions. The results from Week 1 of data collection in Phase 1 indicated that approximately $89 \%$ ( 8 of 9) of all participants reported confusion and misunderstanding regarding use of the DLI. However, based on data analysis from interviews across the 5 weeks of team engagement, final analysis of Phase 1 results indicated that $100 \%$ (9 of 9) of all participants reported that the DLI had improved over time and was now clear and easy to use. This final version of the DLI was used in Phase 2 for establishing content validity of the instrument.

Phase 2: Establishing Content Validity

Following a well-documented content validity process (Yaghmaie, 2003), a group of STEM content experts reviewed the DLI reflective prompts to determine their adequacy for eliciting participant demonstration of STEM content knowledge transfer. This process utilized four experts who were chosen for their expertise in a STEM field or in educational psychology. Each expert had published extensively in their field and was knowledgeable in the area of transfer. Experts rated each DLI reflective prompt based on its relevance, clarity, simplicity, and ambiguity using a 4-point Likert scale: (1) strongly disagree, (2) disagree, (3) agree, and (4) strongly agree (Yaghmaie, 2003). Of the four variables, ambiguity was rated using a reverse scale.

Analysis of expert ratings utilized the Content Validity Index (CVI) developed by Waltz and Bausell (1983), which is the "proportion of items [criteria] given a rating of 3 or 4 by the raters involved" (p. 71) if using a 4-point Likert scale. As suggested by Yaghmaie (2003), only those criteria receiving a CVI score of 0.75 or higher were considered suitable for the study as written. As part of the protocol followed during each consensus meeting, experts met to present their ratings and discuss the DLI reflective prompts. Discussions regarding ratings and possible ways to improve each reflective prompt continued until consensus among all experts was reached for necessary DLI revisions. Table 2 shows consensus results of the CVI ratings for each of the DLI reflective prompts. 
Table 2

Content Validity Consensus Results

\begin{tabular}{clc}
\hline Prompt \# & \multicolumn{1}{c}{ DLI reflective prompt } & $\begin{array}{c}\text { CVI } \\
\text { score }\end{array}$ \\
\hline 0 & $\begin{array}{l}\text { Which phase(s) of the design process are you currently } \\
\text { in? Please circle the phase(s). }\end{array}$ & 1 \\
\hline 1 & $\begin{array}{l}\text { Look at your notes on the previous page and identify the } \\
\text { main topics that were discussed during this work } \\
\text { session. }\end{array}$ & .917 \\
\hline 2 & $\begin{array}{l}\text { Considering the phase(s) you indicated on the previous } \\
\text { page and the main topics you listed in question one, } \\
\text { what Science, Technology, Engineering, and }\end{array}$ & .75 \\
& $\begin{array}{l}\text { Mathematics (STEM) content did you know and what } \\
\text { STEM content did you not know about each topic? }\end{array}$ & \\
\hline 3 & $\begin{array}{l}\text { List any design constraints, design trade-offs, or design } \\
\text { failures that you were confronted with during this work } \\
\text { session. Then explain how what you were confronted } \\
\text { with allowed you to improve your proposal (design } \\
\text { solution). }\end{array}$ & .75 \\
\hline 4 & $\begin{array}{l}\text { Looking at the design constraints, design trade-offs, or } \\
\text { design failures you listed in question three, how do those } \\
\text { modifications affect your original proposal (design) } \\
\text { scenario criteria? }\end{array}$ & .50 \\
\hline 5 & $\begin{array}{l}\text { From the effects stated in question four, how do you } \\
\text { predict they will influence your final proposal (design } \\
\text { solution)? Explain your answer. }\end{array}$ & .75 \\
\hline
\end{tabular}

Note. CVI = Content Validity Index.

Of the six reflective prompts analyzed, Reflective Prompt 4 received a CVI score of less than 0.75 and therefore required further discussion among experts in order to improve the item and reach consensus on content validity. Experts agreed that the content and sequence of the original Reflective Prompts 3 and 4 were confusing and that participants might not understand the difference between their final proposal and their original proposal. In resolving this issue, experts reached consensus that participants should simply list the design constraints, design trade-offs, and design failures in Reflective Prompt 3. In so doing, it clarified that the required responses to Reflective Prompt 4 were now asking specifically for an explanation of how each variable led the designers toward making changes in their original proposal. All of these modifications resulted in a sixth iteration of the DLI for use in Phase 3 of this study. In addition to establishing content validity for the reflective prompts, experts were also tasked with reaching consensus on suggested modifications (Table 3) for improving the readability and clarity of each item. Collectively, final 
conclusions from the expert analyses resulted in DLI reflective prompts that were more cohesive and specific in their ability to guide participants in generating responses with the potential for evidencing knowledge transfer.

Table 3

Phase 2 Revisions of DLI Reflective Prompts

\begin{tabular}{|c|c|c|}
\hline Prompt \# & Initial reflective prompt & Revised reflective prompt \\
\hline 1 & $\begin{array}{l}\text { Look at your notes on the } \\
\text { previous page and identify the } \\
\text { main topics that were discussed } \\
\text { during this work session. }\end{array}$ & $\begin{array}{l}\text { Look at your notes on the } \\
\text { previous page, then identify } \\
\text { and list the main topics that } \\
\text { were discussed during this } \\
\text { work session. }\end{array}$ \\
\hline 2 & $\begin{array}{l}\text { Considering the phase(s) you } \\
\text { indicated on the previous page } \\
\text { and the main topics you listed in } \\
\text { question one, what Science, } \\
\text { Technology, Engineering, and } \\
\text { Mathematics (STEM) content } \\
\text { did you know and what STEM } \\
\text { content did you not know about } \\
\text { each topic? }\end{array}$ & $\begin{array}{l}\text { Considering the main topics } \\
\text { you listed in question one, } \\
\text { describe what Science, } \\
\text { Technology, Engineering, and } \\
\text { Mathematics (STEM) content } \\
\text { you knew and what STEM } \\
\text { content you did not know } \\
\text { about each topic? }\end{array}$ \\
\hline 3 & $\begin{array}{l}\text { List any design constraints, } \\
\text { design trade-offs, or design } \\
\text { failures that you were confronted } \\
\text { with during this work session. } \\
\text { Then explain how what you } \\
\text { were confronted with allowed } \\
\text { you to improve your proposal } \\
\text { (design solution). }\end{array}$ & $\begin{array}{l}\text { List any design constraints, } \\
\text { design trade-offs, or design } \\
\text { failures that you were } \\
\text { confronted with during this } \\
\text { work session. }\end{array}$ \\
\hline 4 & $\begin{array}{l}\text { Looking at the design } \\
\text { constraints, design trade-offs, or } \\
\text { design failures you listed in } \\
\text { question three, how do those } \\
\text { modifications affect your } \\
\text { original proposal (design) } \\
\text { scenario criteria? }\end{array}$ & $\begin{array}{l}\text { Explain how these design } \\
\text { constraints, design trade-offs, } \\
\text { or design failures led you to } \\
\text { change your proposal. }\end{array}$ \\
\hline 5 & $\begin{array}{l}\text { From the effects stated in } \\
\text { question four, how do you } \\
\text { predict they will influence your } \\
\text { final proposal (design solution)? } \\
\text { Explain your answer. }\end{array}$ & $\begin{array}{l}\text { Given your response to } \\
\text { question three, what is your } \\
\text { prediction of how each design } \\
\text { constraint, design trade-off, or } \\
\text { design failure will affect your } \\
\text { final proposal? Explain your } \\
\text { answer. }\end{array}$ \\
\hline
\end{tabular}


Phase Three: Establishing Construct Validity

Establishment of construct validity in this study was critical in determining the degree to which the DLI reflective prompts, as validated in Phase 2, would elicit responses that were in alignment with the theoretical construct of knowledge transfer. The test of DLI construct validity took place during Phase 3 with participants from two different design teams using the content validated DLI during a T/E design challenge. While working through two different design problems, participant data from audio/video recordings and field notes were collected during each design session for later analysis and triangulation. After each work session, participants were provided 5 to 10 minutes for entering responses to reflective prompts in their DLI. Individual interviews with each participant were scheduled for mid-phase (Week 3) and end-of-phase (Week 7) points to gather detailed explanations of DLI entries and to clarify how participants were using their knowledge. The same DLI that participants were provided at the beginning of the T/E design challenge was used throughout the project for recording responses.

\section{Interrater Reliability}

An initial coding scheme was developed and tested for interrater reliability using five STEM content raters. STEM content raters were chosen based on their experience with both teaching and research in the field of STEM education. Each rater had 10 or more years of teaching experience in the STEM areas and had published research on design-based learning techniques. Data from each participating team of sophomores were analyzed independently using an established method for achieving interrater reliability. Utilizing the initial coding scheme, raters coded approximately $10 \%$ of the data from each team, about one transcribed audio/video recording per team (Cox \& Cox, 2008; Fink, 1995; Fink $\&$ Kosecoff, 1985). Based on the results of coding by raters, a percent agreement was calculated. This measure is the ratio of the number of criteria on which the raters agreed divided by the total number of criteria: (Total number of agreements / Total number of observations) X 100. An overall percent agreement equal to or higher than $80 \%$ was used as the cutoff point for acceptance (Cox \& Cox, 2008; Fink, 1995; Fink \& Kosecoff, 1985).

\section{Team 1 Data Analysis}

The design challenge for Team 1 dealt with wind energy, asking participants to examine the feasibility of a wind farm based on several specific parameters. The specifics of their design challenge were as follows.

Wind Power in : Governor has expressed strong interest in establishing wind farms in the state as an important new industry. One of the key areas currently under consideration for a wind farm is off the Eastern Shore of $\_$, in the Atlantic and on 1 . The 
governor has asked your engineering consulting group to examine the feasibility of these projects and prepare a brief presentation for members of the state congress who will be asked to support the project. Wind energy is subject to a number of different controversies, including technical (Can it really generate enough power to be worthwhile?), environmental (Will it harm native wildlife?), and social (Will it be an eyesore and destroy tourism?).

Due to the nature of this design challenge, participants would engage in a design-without-make (Barlex \& Trebell, 2008; Hennesey \& McCormick, 1994) and arrive at a plausible solution by working through all but the prototyping phases of T/E design. Table 4 shows a consolidation of results from data analysis for Team 1 spanning 6 weeks. 


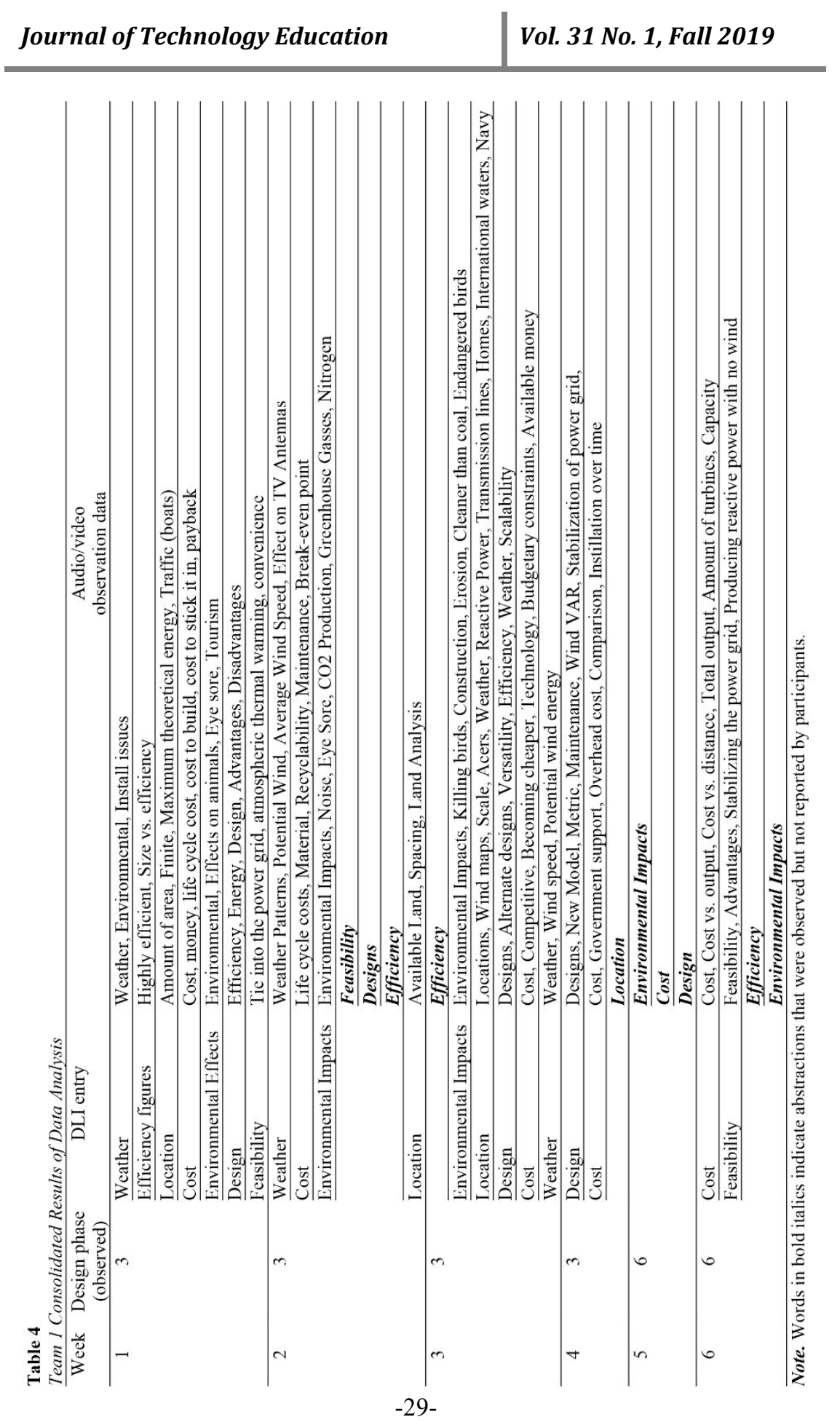


Findings from analysis of Team 1 data indicated that the DLI was $67 \%$ reliable with Team 1 over 6 weeks. Of importance to note in Table 4 are the data represented in bold italics that reflect observed abstractions not reported by participants. The DLI reliability per week is shown in Table 5.

Table 5

Team 1 Reliability Ratio

\begin{tabular}{ccccc}
\hline $\begin{array}{c}\text { Work } \\
\text { sessions }\end{array}$ & $\begin{array}{c}\text { Observed } \\
\text { abstractions }\end{array}$ & $\begin{array}{c}\text { Reported } \\
\text { abstractions } \\
\text { (DLI) }\end{array}$ & $\begin{array}{c}\text { Reliability ratio } \\
\text { (reported / } \\
\text { observed) }\end{array}$ & $\begin{array}{c}\text { Average } \\
\text { reliability } \\
\left(\sum \text { reported / } \Sigma\right. \\
\text { observed) }\end{array}$ \\
\hline 1 & 7 & 7 & $100 \%$ & \\
2 & 7 & 4 & $57 \%$ & \\
3 & 6 & 5 & $83 \%$ & \\
4 & 3 & 2 & $67 \%$ & \\
5 & 3 & 0 & $0 \%$ & $67 \%$ \\
6 & - & - & - & \\
7 & 4 & 2 & $50 \%$ & \\
\hline Total & 30 & 20 & & \\
\hline
\end{tabular}

Note. The team did not meet for Work Session 6.

\section{Team 2 Data Analysis}

The design challenge for Team 2 dealt with creating an exercise regimen. The specifics of their design challenge were as follows.

Exercise for Bone Health: A recent report in the raised questions about the types of exercise individuals should engage in to maintain healthy bones. Confused by the conflicting findings reported in the magazine, a group of family physicians has asked your biomechanics research group to come give a talk at their next monthly meeting. They'd like your group to give them guidelines that they can use for recommending exercise programs for their older patients in particular. Note that these doctors are general practitioners, not orthopedists or gerontologists or related specialists. They are concerned both about what kinds of exercise will help their patients and about what exercises they can reasonably expect their patients to engage in.

As previously explained, participants in Team 2 similarly engaged in a designwithout-make (Barlex \& Trebell, 2008; Hennesey \& McCormick, 1994) engineering challenge, and were to arrive at a plausible solution by working through all but the prototyping phases of $\mathrm{T} / \mathrm{E}$ design. The results of data analysis for Team 2 appear in Table 6. 


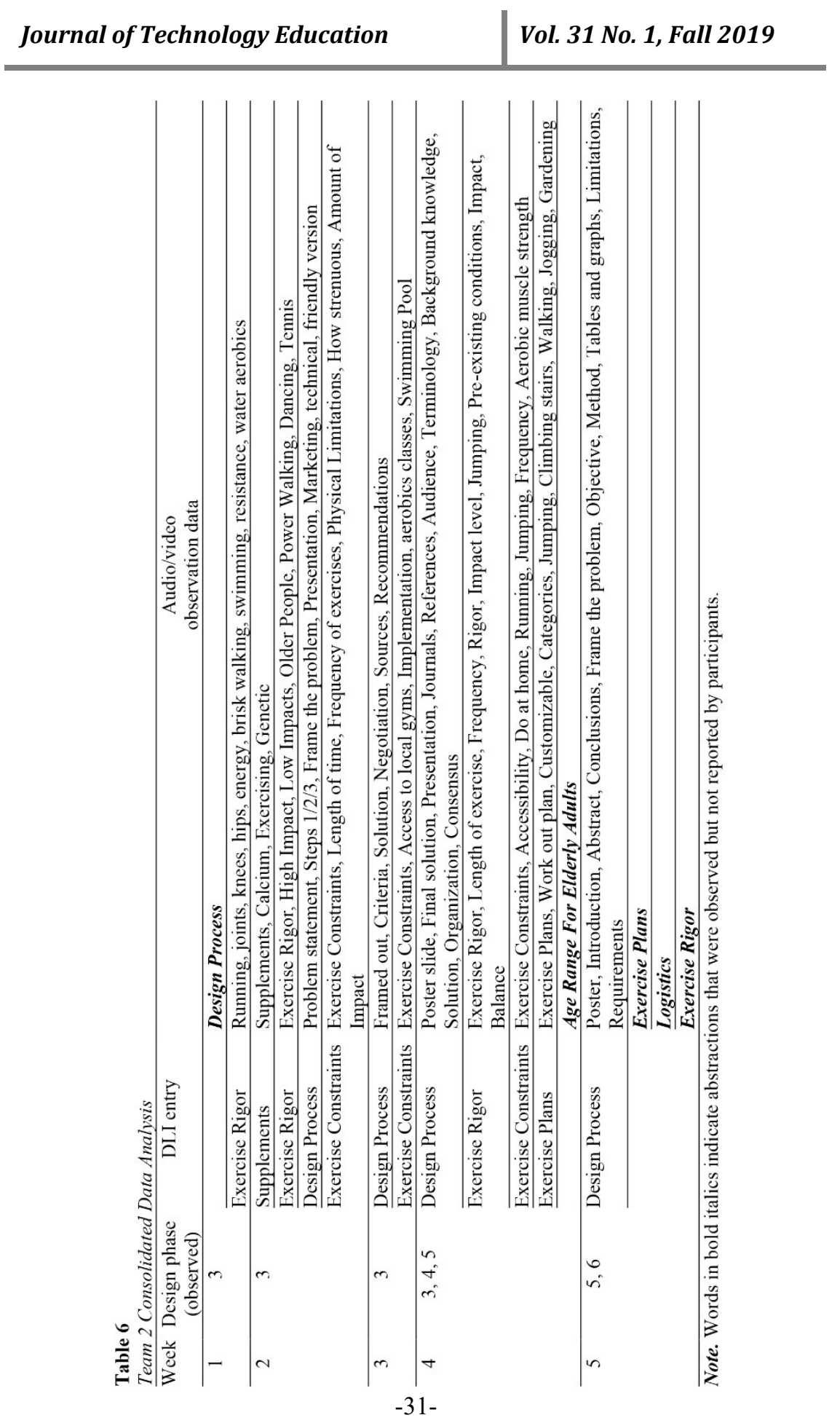


Findings from analyses of Team 2 data indicated that the DLI was $70 \%$ reliable over 5 weeks (see Table 7).

Table 7

Team 2 Reliability Ratio

\begin{tabular}{ccccc}
\hline $\begin{array}{c}\text { Work } \\
\text { sessions }\end{array}$ & $\begin{array}{c}\text { Observed } \\
\text { abstractions }\end{array}$ & $\begin{array}{c}\text { Reported } \\
\text { abstractions } \\
\text { (DLI) }\end{array}$ & $\begin{array}{c}\text { Reliability } \\
\text { ratio } \\
\text { (reported / } \\
\text { observed) }\end{array}$ & $\begin{array}{c}\text { Average } \\
\text { reliability } \\
\left(\sum \text { reported / } \sum\right. \\
\text { observed) }\end{array}$ \\
\hline 1 & 2 & 1 & $50 \%$ & \\
2 & 4 & 4 & $100 \%$ & \\
3 & - & - & - & \\
4 & - & - & - & \\
5 & 2 & 2 & $100 \%$ & \\
6 & 5 & 4 & $80 \%$ & $70 \%$ \\
7 & 4 & 1 & $25 \%$ & \\
\hline Total & 17 & 12 & &
\end{tabular}

Note. The team did not meet for Work Sessions 3 and 4.

\section{Teams 1 and 2: Combined Data Analysis}

Using results from independent analysis of data from Teams 1 and 2, an average reliability of the DLI over the entirety of Phase 3 could be calculated. Analysis of the combined data from Teams 1 and 2 (DLI responses, audio/video transcripts, field notes, interviews per work session) found there to be a $68 \%$ average level of reliability (see Table 8) across all seven work sessions.

Table 8

Combined Teams Reliability Ratio

\begin{tabular}{|c|c|c|c|c|}
\hline $\begin{array}{l}\text { Work } \\
\text { sessions }\end{array}$ & $\begin{array}{c}\text { Observed } \\
\text { abstractions }\end{array}$ & $\begin{array}{l}\text { Reported } \\
\text { abstractions } \\
\text { (DLI) }\end{array}$ & $\begin{array}{c}\text { Reliability } \\
\text { ratio (reported } \\
\text { / observed) }\end{array}$ & $\begin{array}{c}\text { Average } \\
\text { reliability } \\
\left(\sum \text { reported / }\right. \\
\left.\sum \text { observed }\right)\end{array}$ \\
\hline 1 & 9 & 8 & $88 \%$ & \\
\hline 2 & 11 & 8 & $72 \%$ & \\
\hline 3 & 6 & 5 & $83 \%$ & \\
\hline 4 & 3 & 2 & $67 \%$ & \\
\hline 5 & 5 & 2 & $40 \%$ & \\
\hline 6 & 5 & 4 & $80 \%$ & \\
\hline 7 & 8 & 3 & $37.5 \%$ & \\
\hline Total & 17 & 32 & & $68 \%$ \\
\hline
\end{tabular}


Prompt 2. Further analyses of data gathered across all seven work sessions per individual DLI reflective prompt was also conducted in order to reveal the relative strength of each criterion for eliciting STEM content knowledge transfer. The percent abstractions found per DLI reflective prompt appear in Table 9 . The analysis indicated that the majority of the abstractions (36\%) were revealed through participant responses to DLI Reflective Prompt 2 in which they were asked to describe what STEM content knowledge they knew and did not know regarding the topic of the design challenge.

Table 9

Percentage of Abstractions Found Per DLI Reflective Prompt

\begin{tabular}{clc}
\hline Prompt \# & \multicolumn{1}{c}{ DLI reflective prompt } & $\%$ abstractions \\
\hline 1 & $\begin{array}{l}\text { Look at your notes on the previous page, then } \\
\text { identify and list the main topics that were } \\
\text { discussed during this work session. }\end{array}$ & $20 \%$ \\
\hline 2 & $\begin{array}{l}\text { Considering the main topics you listed in } \\
\text { question one, describe what Science, } \\
\text { Technology, Engineering, and Mathematics } \\
\text { (STEM) content you knew and what STEM } \\
\text { content you did not know about each topic? }\end{array}$ & $36 \%$ \\
\hline 3 & $\begin{array}{l}\text { List any design constraints, design trade-offs, } \\
\text { or design failures that you were confronted } \\
\text { with during this work session. }\end{array}$ & $22 \%$ \\
\hline 4 & $\begin{array}{l}\text { Explain how these design constraints, design } \\
\text { trade-offs, or design failures led you to change } \\
\text { your proposal. }\end{array}$ & \\
\hline 5 & $\begin{array}{l}\text { Given your response to question three, what is } \\
\text { your prediction of how each design constraint, } \\
\text { design trade-off, or design failure will affect } \\
\text { your final proposal? Explain your answer. }\end{array}$ & \\
\hline
\end{tabular}

The DLI reflective prompts were purposefully developed to align with the phases of the T/E design process, and data collected across all seven work sessions were again analyzed per phase of the T/E design process. In this study, participants were presented with a prescribed context and challenge (identified problem, including parameters and criteria), which resulted in initiating their T/E Design primarily working within Phase 3 of the design process. Analysis of this data indicated that the majority of abstractions occurred during Design Phase 3, which corresponds with Reflective Prompt 2 of the DLI. This analysis suggests that when participants are investigating a problem, they begin with an evaluation of what is known and unknown, which predisposes them to transfer of STEM content knowledge. Similarly, when participants are tasked with choosing a solution and developing that solution, they are confronted with 
design constraints, design trade-offs, and design failures. To resolve issues that arise from these design parameters, participants must draw on their resident knowledge of STEM content (knowledge domain) in order to envision plausible solutions (concept domain), making strategic decisions based on disciplinary connections (Wells, 2016b, 2017). The percent of abstractions associated with each $\mathrm{T} / \mathrm{E}$ design phase are presented in Table 10.

Table 10

Percentage of Abstractions Found Per T/E Design Phase

\begin{tabular}{clc}
\hline $\begin{array}{c}\text { Design } \\
\text { phase \# }\end{array}$ & \multicolumn{1}{c}{ T/E design process phase description } & $\%$ abstractions \\
\hline 1 & $\begin{array}{l}\text { Identify a problem either by observation or a } \\
\text { human need }\end{array}$ & $0 \%$ \\
\hline 2 & Frame criteria for the final solution & $0 \%$ \\
\hline 3 & Investigate what is known about the problem & $71 \%$ \\
\hline 4 & Develop alternate solutions to the problem & $5 \%$ \\
\hline 5 & $\begin{array}{l}\text { Choose an appropriate solution from the } \\
\text { alternate solutions }\end{array}$ & $10 \%$ \\
\hline 6 & $\begin{array}{l}\text { Develop detailed plans for constructing your } \\
\text { chosen solution }\end{array}$ & $14 \%$ \\
\hline 7 & $\begin{array}{l}\text { Simulate or prototype your chosen solution } \\
\text { Check to see if your chosen solution meets the } \\
\text { criteria that were identified earlier }\end{array}$ & $0 \%$ \\
\hline 9 & $\begin{array}{l}\text { If the chosen solution does not meet the criteria } \\
\text { make any improvements necessary and present } \\
\text { your findings }\end{array}$ & $0 \%$ \\
\hline
\end{tabular}

Prompt 4. Results from the data analysis also revealed that participants were not responding well to Reflective Prompt 4, which accounted for only 9\% of total abstractions identified during Phase 3 (see Table 9). When prompted during mid-phase interviews (Week 3 ) to discuss why, participants reported that they did not feel as though they had a proposal to change until later in the T/E design process. However, when prompted further during interviews to verbalize how their thinking changed, $100 \%$ (9 of 9) of participants were able to respond to this prompt. Based on these findings, at the end of Phase 3, Reflective Prompt 4 was modified to ask participants how design constraints, design trade-offs, or design failures led them to change their thinking on the project. This modification of Reflective Prompt 4 was incorporated into the final iteration of the DLI (see Table 11). 
Table 11

Final DLI Reflective Prompt Revisions

\begin{tabular}{|c|c|c|}
\hline $\begin{array}{c}\text { Prompt } \\
\text { \# }\end{array}$ & Initial reflective prompt & Final reflective prompt \\
\hline 1 & $\begin{array}{l}\text { Look at your notes on the } \\
\text { previous page, then identify and } \\
\text { list the main topics that were } \\
\text { discussed during this work } \\
\text { session. }\end{array}$ & $\begin{array}{l}\text { Look at your notes on the } \\
\text { previous page, then identify and } \\
\text { list the main topics that were } \\
\text { discussed during this work } \\
\text { session. }\end{array}$ \\
\hline 2 & $\begin{array}{l}\text { Considering the main topics you } \\
\text { listed in question one, describe } \\
\text { what Science, Technology, } \\
\text { Engineering, and Mathematics } \\
\text { (STEM) content you knew and } \\
\text { what STEM content you did not } \\
\text { know about each topic? }\end{array}$ & $\begin{array}{l}\text { Considering the main topics you } \\
\text { listed in question one, describe } \\
\text { what Science, Technology, } \\
\text { Engineering, and Mathematics } \\
\text { (STEM) content you knew and } \\
\text { what STEM content you did not } \\
\text { know about each topic? }\end{array}$ \\
\hline 3 & $\begin{array}{l}\text { List any design constraints, } \\
\text { design trade-offs, or design } \\
\text { failures that you were } \\
\text { confronted with during this } \\
\text { work session. }\end{array}$ & $\begin{array}{l}\text { List any design constraints, } \\
\text { design trade-offs, or design } \\
\text { failures that you were } \\
\text { confronted with during this } \\
\text { work session. }\end{array}$ \\
\hline 4 & $\begin{array}{l}\text { Explain how these design } \\
\text { constraints, design trade-offs, or } \\
\text { design failures led you to } \\
\text { change your proposal. }\end{array}$ & $\begin{array}{l}\text { Explain how these design } \\
\text { constraints, design trade-offs, or } \\
\text { design failures led you to } \\
\text { change your thinking of the } \\
\text { project. }\end{array}$ \\
\hline 5 & $\begin{array}{l}\text { Given your response to question } \\
\text { three, what is your prediction of } \\
\text { how each design constraint, } \\
\text { design trade-off, or design } \\
\text { failure will affect your final } \\
\text { proposal? Explain your answer. }\end{array}$ & $\begin{array}{l}\text { Given your response to question } \\
\text { three, what is your prediction of } \\
\text { how each design constraint, } \\
\text { design trade-off, or design } \\
\text { failure will affect your final } \\
\text { proposal? Explain your answer. }\end{array}$ \\
\hline
\end{tabular}

\section{Conclusions}

The first research sub-question (RQ-S1) dealt with development of the phrasing for the DLI reflective prompts: What phrasing of design log reflective prompts effectively reveal STEM content connections? To answer this question, the DLI was tested, evaluated, and refined throughout all three phases of this research. At the conclusion of Phase 2, the DLI contained reflective prompts that were content valid and poised for testing of their ability to provide evidence of STEM content knowledge transfer. Testing of the DLI took place in Phase 3 in which data were collected from two teams working independently through 
different engineering design challenges. Analysis of these data resulted in a final iteration of the five reflective prompts, as illustrated in Table 11.

Throughout this study, each revision of the reflective prompts became more specific, encouraging participants to respond in a precise way. Analysis of data derived from both DLI responses and interview responses allowed better recognition and understanding of points at which disconnects were occurring. This process proved ideal for using specific participant feedback to construct reflective prompts that more closely represented language and content that participants were familiar with while preserving the types of data that were necessary for this study.

The second research sub-question (RQ-S2) asked the following question: To what extent can a DLI allow a researcher to make judgments regarding the transfer of STEM content knowledge? Data collected in this study consisted of audio/video recordings, field notes, interviews, and DLI responses. Through iterative revisions of the DLI, the goal was to develop a set of reflective prompts that would aid in the independent collection of data reflecting knowledge transfer without the additional need for audio/video recordings, field notes, and interviews.

Findings in Phase 3 of this research indicate that the DLI shows the potential for being $68 \%$ reliable (see Table 8 ) as an independent measure of knowledge transfer. Meaning that $68 \%$ of the time, the DLI would consistently provide data similar to that derived through triangulation of the audio/video recordings, field notes, and interviews (Cox \& Cox, 2008, p. 40; Fink, 1995; Fink \& Kosecoff, 1985) and could serve as an independent method of data collection. Although the reliability of the DLI is relatively high, reflective prompts must be further developed to foster greater discussion of topics. The triangulation data provides a deep level of insight into how knowledge is used to solve problems that the DLI alone, in its current form, does not. In order for the DLI to truly be used as an independent measure of STEM content knowledge transfer, this insight must be present in DLI responses. Further refinement and development may improve the reliability of the DLI and the ability of the reflective prompts to elicit responses that not only provide evidence of STEM content knowledge transfer but also explain those instances.

The overarching question of this study was: In what ways does the use of a design log provide evidence of the transfer of STEM content knowledge while students are engaged in a T/E design-based learning activity? Data analyzed to answer each sub-question provided direction in answering this overarching question. As this study progressed, the DLI required fewer substantial changes, indicating that as time went on, the DLI was more accurately providing evidence of knowledge transfer. At the end of Phase 3, the DLI showed the potential to be $68 \%$ reliable as an independent measure of STEM content knowledge transfer. Though this shows a degree of success with the instrument, it is still not reliable enough for use as an independent source of data. Participants were providing 
evidence of STEM content knowledge transfer in their DLI responses, but they were not providing as many instances as were identified in the observation data (audio/video recordings and field notes).

Participants also gave rather simple explanations of topics discussed during their team work sessions that did not corroborate the more robust descriptions provided by the observation data. There are several plausible reasons for the gap between the observed and reported abstractions. Knowledge abstraction is more likely to occur in some T/E design phases than in others. It is plausible that participants did not recognize that they were abstracting knowledge but rather thought they were applying knowledge from a previous design phase. For example, $71 \%$ of the total abstractions occurred during T/E Design Phase 3, which dealt with investigating the problem. Participants used the abstracted knowledge gained during this phase and applied it to develop alternate solutions during T/E Design Phase 4. Although participants did not report abstractions during this design phase, observation data shows that participants were abstracting knowledge, causing the gap between observed and reported abstractions. It is also possible that motivation may have affected a participant's willingness to respond to DLI reflective prompts. The DLI required participants to do additional work after each work session; thus, fatigue may have caused them to respond without the effort necessary to provide meaningful data. For these reasons, assigning STEM content codes to abstractions found in the DLI responses was difficult without the accompanying observation data.

Participants in both Phase 1 (the pilot study) and Phase 3 (implementation) reported that the DLI provided a valuable record of design decisions throughout the T/E design process. During both mid-phase (Week 3) and end-of-phase (Week 7) interviews, $100 \%$ of the participants reported that required journaling in the DLI allowed them to keep track of past decisions and reflect on them while making new decisions. This level of reflection improved the ability of participants to make informed decisions and to consider the positives and negatives of each. Specifically, in Phase 3, as an unintended outcome, the DLI allowed participants to monitor their own learning and acted as a guide through the $\mathrm{T} / \mathrm{E}$ design process. In this way, there is potential to use the DLI as an instructional tool as well as a method for collecting data.

Although the DLI is not yet ready to be used as an independent measure of STEM content knowledge transfer at this time, it does show promise for providing such data independently. With future iterations, the reliability of the DLI can increase as an independent instrument. The intended target audience for this instrument was students in undergraduate programs that engaged them in $\mathrm{T} / \mathrm{E}$ design challenges. The reliability of this instrument is also bound to the studied context and therefore needs further development in other contexts to verify the reliability. 


\section{Implications}

This study provides the first step in developing an instrument that can be used by TEE to evidence transfer through abstraction. Although the instrument cannot be used in its current form with all TEE students, the groundwork has been laid, and future studies may bring us to that point. This research provides additional support for T/E design-based learning as a valuable pedagogical approach to teaching and learning that fosters a deep understanding of STEM content and practice. For TEE to contribute to the body of research generated by other core STEM disciplines, similar cognitive investigations will need to become a larger part of the TEE research agenda.

This study represents an initial instrument development examining the first half of the T/E design process. The researchers believed that the first half of the design process is where students conceptualize a possible solution and utilize an integrated approach that is discipline agnostic. It was at this stage that we felt we were most likely to identify instances of knowledge transfer. Due to the nature of the challenges used, the participants, and using the first half of the design process, the findings of this study are not generalizable. However, the initial findings have given the researchers a good foundation for further refinement. In a future study, we will use a larger population and utilize a $\mathrm{T} / \mathrm{E}$ design challenge that encompasses the entire design process, thus allowing for an improved instrument that can be used with a broader population.

Note: This article was based on the first author's dissertation study (see Figliano, 2011). This study was also previously discussed in a conference paper (Figliano \& Wells, 2012).

\section{References}

Anderson, J. R. (2005). Cognitive psychology and its implications (6th ed.). New York, NY: Worth.

Barlex, D., \& Trebell, D. (2008). Design-without-make: challenging the conventional approach to teaching and learning in a design and technology classroom. International Journal of Technology and Design Education, 18(2), 118-138. doi:10.1007/s10798-007-9025-5

Change the Equation. (2016). Left to Chance: U.S. middle schoolers lack indepth experience with technology and engineering. Vital Signs. Retrieved from http://changetheequation.org/left-to-chance

Cox, J., \& Cox, K. B. (2008). Your opinion, please: How to build the best questionnaires in the field of education (2nd ed.). Thousand Oaks, CA: Corwin Press.

Figliano, F. J. (2011). Development of an instrument to evidence knowledge abstractions in technological/engineering design-based activities (Doctoral 
dissertation). Available from ProQuest Dissertations and Theses database. (UMI No. DP19961)

Figliano, F. J., \& Wells, J. G. (2012, March). Knowledge abstraction in technological/engineering design activities. Paper presented at the Council on Technology \& Engineering Teacher Education Conference, Long Beach, CA. Retrieved from http://ctete.org/wpcontent/uploads/2016/03/Figliano_Wells_Final.pdf

Fink, A. (1995). The survey handbook. Thousand Oaks, CA: Sage.

Fink, A., \& Kosecoff, J. B. (1985). How to conduct surveys: A step-by-step guide. London, England: Sage.

Hennessy, S., \& McCormick, R. (1994). The general problem-solving process in technology education. Myth or reality? In F. Banks (Ed.), Teaching technology (pp. 94-108). London, England: Routledge.

Hill, R. B. (1997). The design of an instrument to assess problem solving activities in technology education. Journal of Technology Education, 9(1), 31-46. doi:10.21061/jte.v9i1.a.3

Honey, M., Pearson, G., \& Schweingruber, H. (Eds.). (2014). STEM integration in $\mathrm{K}-12$ education: Status, prospects, and an agenda for research. Washington, DC: National Academies Press. doi:10.17226/18612

International Technology and Engineering Educators Association. (2015). ITEEA in a box. Reston, VA: Author. Retrieved from https://www.iteea.org/File.aspx?id=90060\&v=5e1d6c4c

Katehi, L., Pearson, G., \& Feder, M. (Eds.). (2009). Engineering in K-12 education: Understanding the status and improving the prospects. Washington, DC: National Academies Press. doi:10.17226/12635

Kelly, T. R. (2008). Cognitive processes of students participating in engineering-focused design instruction. Journal of Technology Education, 19(2), 50-64. doi:10.21061/jte.v10i2.a.4

Kolodner, J. L. (2002). Facilitating the learning of design practices: Lessons learned from an inquiry into science education. Journal of Industrial Teacher Education, 39(3), 9-40.

Kolodner, J. L., Camp, P. J., Crismond, D., Fasse, B., Gray, J., Holbrook, J., . . . Ryan, M. (2003). Problem-based learning meets case-based reasoning in the middle-school science classroom: Putting Learning by Design ${ }^{\mathrm{TM}}$ into practice. Journal of the Learning Sciences, 12(4), 495-547. doi:10.1207/S15327809JLS1204_2

National Research Council. (2011). Successful K-12 STEM education: Identifying effective approaches in science, technology, engineering, and mathematics. Washington, DC: National Academies Press. doi:10.17226/13158

Partnership for 21st Century Skills. (2011). Framework for 21 st century learning. Retrieved from http://www.p21.org/our-work/p21-framework 
Pitts Bannister, V. R., \& Mariano, G. J. (2015). IBL and mathematics: The necessity of flexible knowledge. In P. Blessinger \& J. M. Carfora (Eds.), Inquiry-based learning for science, technology, engineering, and math (STEM) programs: A conceptual and practical resource for educators (pp. 135-149). Bingley, United Kingdom: Emerald Group. doi:10.1108/S2055364120150000004009

Puntambekar, S., \& Kolodner, J. L. (1998). The design diary: A tool to support students in learning science by design. In A. S. Bruckman, M. Guzdial, J. L. Kolodner, \& A. Ram (Eds.), Proceedings of the International Conference of the Learning Sciences (pp. 35-41). Charlottesville, VA: Association for the Advancement of Computing in Education.

Puntambekar, S., \& Kolodner, J. L. (2005). Toward implementing distributed scaffolding: Helping students learn science from design. Journal of Research in Science Teaching. 42(2), 185-217. doi:10.1002/tea.20048

Puri, I. K. (2008). Welcome from the department head. Engineering sciences and mechanics website. Retrieved May 14, 2010.

Virginia Polytechnic Institute and State University. (2019). Integrative STEM education. Retrieved from https://liberalarts.vt.edu/departments-andschools/school-of-education/academic-programs/integrative-stemeducation.html/

Waltz, C. F., \& Bausell, R. B. (1983). Nursing research: Design, statistics and computer analysis (2nd ed.). Philadelphia, PA: Davis.

Wells, J. G. (2008, November). STEM Education: The potential of technology education. Paper presented at the $95^{\text {th }}$ Mississippi Valley Technology Teacher Education Conference, St. Louis, MO.

Wells, J. G. (2010). Research on teaching and learning in science education: Potentials for technology education. In P. A. Reed \& J. E. LaPorte (Eds.), Research in Technology Education (pp. 182-202). 59th Yearbook of the Council on Technology Teacher Education. Reston, VA: Council on Technology Teacher Education.

Wells, J. G. (2016a). PIRPOSAL Model of Integrative STEM Education: Conceptual and Pedagogical Framework for Classroom Implementation. Technology and Engineering Teacher, 75(6), 12-19.

Wells, J. G. (2016b). Efficacy of the technological/engineering design approach: Imposed cognitive demands within design based biotechnology instruction. Journal of Technology Education, 27(2), 4-20. doi:10.21061/jte.v27i2.a.1

Wells, J. G. (2017). Design to understand: Promoting higher order thinking through T/E design based learning. In Proceedings of the Technology Education New Zealand and International Conference on Technology Education-Asia Pacific (pp. 325-339). Hamilton, New Zealand: TEMS Education Research Center, University of Waikato. Retrieved from https://tenz.org.nz/wp-content/uploads/2018/03/TENZICTE-2017proceedings.pdf 
Yaghmaie, F. (2003). Content validity and its estimation. Journal of Medical Education, 3(1), 25-27. Retrieved from

http://journals.sbmu.ac.ir/jme/article/view/870/769

Yin, R. K. (2009). Case study research: Design and methods (4th ed.). Thousand Oaks, CA: Sage.

\section{About the Authors}

Fred J. Figliano (ffigliano@troy.edu) is Assistant Professor in the College of Education at Troy University.

John G. Wells (jgwells@vt.edu) is Professor in the School of Education at Virginia Tech. 